\title{
DINAMIKA HUKUM ISLAM DAN PERUBAHAN SOSIAL
}

\author{
Titin Samsudin \\ INSTITUT AGAMA ISLAM NEGERI GORONTALO \\ Email :nurulhubbi@gmail.com
}

\begin{abstract}
The dynamism of Islamic law must have an effect on the process of social interaction. In vice versa, social status that absorbed through interaction between religion and society will have an implication to the social process. social change in society always demands changes in the law, so legal change can lead to social change. Sociologically, the society always changes. The change of a society can be influenced by the way of thinking and the value of existing in society. The more advanced the way of thinking of a society will be more open problematika that happened, The more problematic faced by society hence the settlement demand also getting harder. So it takes a serious effort in solving it. Thus the role of Islamic law in answering all issues that are increasingly growing in the social community is very urgent done. As an illustration and concrete and concrete form of the dynamic of Islamic law.
\end{abstract}

Keywords: Dynamization, Islamic Law, Social Change.

\begin{abstract}
Abstrak
Dinamisasi hukum Islam pastilah berpengaruh terhadap proses interaksi sosial. demikian pula sebaliknya status sosial yang terserap melalui interaksi antara agama dan masyarakat akan berimplikasi terhadap proses sosial. perubahan sosial dalam masyarakat selalu menuntut adanya perubahan hukum, demikian pula perubahan hukum dapat menimbulkan perubahan sosial. Secara sosiologis masyarakat senantiasa mengalami perubahan. Perubahan suatu masyarakat dapat dipengaruhi oleh polapikir dan tata nilai yang ada dalam masyarakat. Semakin maju cara berpikir suatu masyarakat maka akan semakin
\end{abstract}


terbuka problematika yang terjadi, Semakin banyak problematika yang dihadapi oleh masyarakat maka tuntutan penyelesaiannya juga semakin berat. Sehingga membutuhkan upaya yang sungguh-sungguh dalam menyelesaikannya. Dengan demikian peranan hukum Islam dalam menjawab semua persoalan yang semakin hari semakin berkembang dalam sosial masyarakat sangatlah urgen dilakukan. Sebagai gambaran dan bentuk konkrit serta nyata dari dinamisnya hukum Islam.

Kata kunci : Dinamisasi, Hukum Islam, Perubahan sosial.

\section{PENDAHULUAN}

Salah satu problem krusial yang seringkali muncul dalam kehidupan beragama adalah bagaimana menyikapi doktrin-doktin agama yang tertuang dalam kitab suci dan sumber-sumber otoritas agama lainnya secara adil, agar doktrin-doktrin tersebut tetap memiliki relevansi yang tepat dengan dinamika masyarakat yang selalu berubah, serta selalu bersifat fungsional untuk menyelesaikan problem-problem masyarakat untuk kemudian bisa diadopsi kedalam sistem yang lebih modern dan up to date.

Kondisi real masyarakat masa kini adalah dihadapkan pada dua buah pilihan, yakni berpegang teguh pada norma-norma hukum agama sembari menundukkan realita kehidupan, dan kebutuhan hukum baru dihadapan otoritas hukum agama, atau menanggalkan hukum agama karena ia tak lagi fungsional mengakomodir kebutuhan hukum dan rasa keadilan masyarakat. Terlebih setelah dunia Islam bersentuhan dan berinteraksi dengan westernisasi melalui kolonialisme yang dilakukan Dunia barat kepada Dunia Timur, Khususnya Dunia Islam.

Persentuhan antara peradaban timur dan barat ini berdampak pada terjadinya perubahan-perubahan sosial ${ }^{1}$ yang kemudian melahirkan sejumlah besar problem baru bagi masyarakat Islam, khususnya berkaitan dengan

\footnotetext{
${ }^{1}$ Soejono Soekamto, Sosiologi Suatu Pengantar, XX (Jakarta: Raja Grafindo, 1995), 337.
} 
relevansi agama bagi era modern. Perubahan tersebut banyak melahirkan simbol-simbol sosial dan kultur baru yang secara eksplisit tidak dimiliki oleh simbol keagamaan yang dianggap mapan. Sehingga berbagai aspek pemahaman umat atas doktrin-doktrin agamanya dipertanyakan kembali, bahkan digugat oleh kalangan pembaharu. ${ }^{2}$

Perubahan sosial, itu adalah satu pasti musti terjadi dalam suatu masyarakat. Yang perlu dicatat adalah, bahwa perubahan yang terjadi itu pasti mempengaruhi kehidupan sosial kemasyarakatan suatu kelompok masyarakat. berkenaan dengan adanya perubahan ini, para sosiolog memberikan beberapa titik poin penekanan yang tidak sama antara satu dan yang lainnya. Akan tetapi apapun penekanan yang diberikan para sosiolog itu, mereka telah sepakat bahwa perubahan sosial itu bersifat mempengaruhi dan merubah tatanan sistem sosial yang sudah diasumsikan sebagai sestuatu yang baku sebelumnya oleh suatu masyarakat. ${ }^{3}$

Salah satu aspek pemahaman tersebut adalah, hukum Islam yang dianggap sebagai warisan keagamaan tradisional, dalam bidang sosial ia seringkali dipandang tidak lagi memenuhi kebutuhan zaman. Oleh karenanya, reformasi hukum Islam merupakan suatu keniscayaan. Perubahan-perubahan social yang dihadapi kaum muslim pada periode modern telah menimbulkan sejumlah besar masalah serius berkaitan dengan hukum Islam, namun metode dalam istinbath hukum yang dikembangkan para pembaharu hukum islam guna menjawab persoalan-persoalan yang terus berkembang tersebut, nampaknya belum mampu menyelesaikan apa yang dikatakan sebagai persoalan umat. Dengan demikian kajian tentang dinamika hukum islam ini sangat perlu dilakukan. Agar Supaya dinamisi Hukum Islam dapat menjadi jawaban tantangan dari perubahan sosial yang ada dan terjadi.

\footnotetext{
${ }^{2}$ Martha Mundhy, The Family Inheritence; And Islam: A Re-examination of the Sociology of Faraid Law, dalam Aziz Azmeh (ed.), Islamic Law Social and Historical Contexts, II (London: Routledge, 1998), 1-2.

${ }^{3}$ Zulham Wahyudani Dan Raihanah Hj Azahari, "Perubahan Sosial Dan Kaitannya Dengan Pembagian Harta Warisan Dalam Perspektif Hukum Islam," Jurnal Islam Futura UIN Ar-Raniry Vol 14, no. No 2 (2015): h. 166.
} 


\section{PEMBAHASAN}

\section{HUKUM ISLAM}

Istilah hukum Islam dapa ditemukan dalam literatur Barat, yaitu dengan term Islamic law yang secara harfiah disebut sebagai hukum Islam. Dalam penjelasan tentang kata Islamic law, cenderung didefinisikan sebagai keseluruhan wahyu Allah yang mengatur kehidupan muslim dengan segala aspek kehidupannya. Dari definisi ini terlihat bahwa kata hukum Islam lebih dekat pengertiannya kepada kata syari'at Islam. Namun kata Hukum Islam ini telah diserap kedalam bahasa Indonesia, dan maknanya berubah menjadi syariat. ${ }^{4}$ Padahal dalam perkembangannya, term kata Islamic law bukanlah ditujukan kepada kata syariat, melainkan kepada kata fiqih yang menjadi wilayahnya para fuqaha. Sebenarbya ungkapan yang lebih tepat untuk menggambarkan syari'at bukanlah Islamic Law melainkan Islamic Jurisprudence. ${ }^{5}$

Secara etimologi syariat memiliki dua arti pertama, diartikan sebagai tempat air mengalir seperti perkataan orang Arab shara'tu al-ibil idza waradat syari'at al-ma' (Aku memberi minum untaku ketika ia dating ditempat air) ${ }^{6}$ kedua, memiliki pengertian sebagai jalan yang lurus (al-thariq al-Mustaqim wa al-Wadhih) sebagaimana yang terdapat dalam surat al-Jatsiyah ayat 18 yang artinya; “ kemudian kami jadikan kamu berada di atas suatu syariat (peraturan) dari urusan (agama) itu, maka ikutilah syariat itu dan janganlah kamu ikuti hawa nafsu orang-orang yang tidak mengetahui".

Sedangkan secara terminologi pengertian syariat adalah segala yang diturunkan Allah kepada Rasulullah SAW baik yang terdapat dalam Al-Quran maupun Al-Sunnah yang diyakini kebenarannya. ${ }^{7}$ Namun para ulama juga memberikan definisi yang sempit tentang syariat, yaitu segala titah yang berhu-bungan

\footnotetext{
${ }^{4}$ Departemen Pendidikan Nasional, Kamus Bahasa Indonesia (Jakarta: Pusat Bahasa, 2008), 1402.

${ }^{5}$ Yoyo Hambali, "Hukum Islam Dan Perubahan Sosial : Study Atas Konsep Maslahah Dan Aplikasinya Dalam Keluarga Islam Kontemporer," Jurnal Maslahah Vol. 6, no. No. 2 (November 2015): h. 40.

${ }^{6}$ Muhammad Ali Jum'ah, Al-Madkhal Ila Darasat al-Madzahib al fiqhiyyah (Kairo: Dar al-Salam, 2004), 305.

${ }^{7}$ Amir Syarifuddin, Ushul Fiqh I (Jakarta: Kencana, 2010), 1.
} 
dengan tingkah laku manusia diluar yang mengenai akhlak. Karena itu kata syariat, merupakan nama lain bagi hukum yang bersifat amaliah. ${ }^{8}$

Adapun kata fiqih sangat erat kaitannya dengan kata syariat. Karena fiqih merupakan jabaran sederhana dan praktis dari syariat. Secara etimologi, kata fiqih diambil dari kata faqiha yafqahu faqihan yang memiliki makna mengerti atau paham, lebih jauhnya adalah paham yang mendalam. ${ }^{9}$ Secara terminologi kata fiqih, yakni ilmu tentang hukum-hukum syari'at yang bersifat amalia yang diambil dari dalil-dalilnya yang terperinci. ${ }^{10}$

Dari pemaparan singkat diatas dapat dipahami bahwa istilah syariat dan fiqih digunakan untuk mendeskripsikan Hukum Islam. Kedua istilah tersebut sama-sama membahas hukum Islam, akan tetapi terdapat perbedaan antara keduannya sebagaimana penjelasan di atas. Dimana syariat itu berasal dari Allah dan Rasul-Nya sebagai pembuat syariat, sementara fiqih adalah pengetahuan para fuqaha tentang syariat atau meerupakan pengejawantahan pemikiran mujtahid tentang syariat.

Syari'at adalah Hukum Islam yang masa berlaku berifat qadim atau sepanjang masa, sedangkan fiqih, merupakan rumusan konkrit dan bersifat praktis dari hukum Islam, yang nantinya dapat diaplikasikan dalam suatu kasus, atau tempat, atau keadaan, dan atau masa tertentu. Syari'at dan Fiqih memang berbeda secara subtansi, tetapi tidak juga dapat dipisahkan. Ketentuan ini berlaku karena menghindari terjadinya kerancuan dalam memahami hukum Islam, baik sebagai sebuah ajaran ataupun sebagai hasil penafsiran, interpretasi, pemikiran mujtahid.

Ketetapan hukum pada prinsipnya ada yang sudah bersifat tetap dan final, tidak menerima dan atau menafikkan pembaharuan dan perubahan. Ketentuan hukum Islam yang tetap telah diterangkan dan ditetapkan oleh Alquran dan Sunah secara pasti, jelas dan terperinci. Ketentuan hukum yang bersifat final seperti ini bukan lagi menjadi wilayah lapangan ijtihad.11 Selain itu

\footnotetext{
${ }^{8}$ Ibid

${ }^{9}$ Ibn Manzur, Lisan al-'Arab (t.tp.: Dar al-Ma'arif, t.t.), 3450.

${ }^{10}$ Abu Zahrah, Ushul al-Figh (Mesir: Dar Al-'Arabiy, t.t.), 7.

${ }^{11}$ Abdullah Nashih 'Ulwan, Syari'at Islam yang Abadi (Bandung: Usamah Press, 1992), 38.
} 
terdapat juga ketentuan hukum yang tidak tetap atau final, dan dapat berubahubah, ketentuan hukum yang seperti ini dapat dibedakan menjadi dua macam yaitu: pertama, hukum yang digali dari dalil-dalil zhanni namun berubah secara dinamis. Kedua, hukum yang dihasilkan melalui ijtihad sebagai akibat dan respon dari perkembangan masa. ${ }^{12}$

Dalam teori Ushul fiqih, ijtihad hanya dapat dilakukan pada ranah tertentu yakni: a) dalil-dalil yang qath'i al-wurudh tetapi zhanni dalalah; b) dalildalil yang zhanni al-wurudh tapi qath'i al-dalalah; c) dalil-dalil yang zhanni al-wurud dan dalalahnya; d) terhadap kasus-kasus yang tidak ada dalil hukumnya. ${ }^{13}$ Berkenaan dengan kasus yang belum ada dalil naqlinya ini, maka para pemikir hukum Islam harus mulai memperhatikan secara lebih seksama dan mengkaji kembali teori-teori/kaidah-kaidah ushul fiqh yang ada, agar kemudian dapat dilakukan ijtihad, yang nantinya akan memberikan fatwa atau pegangan hukum yang progresif bagi umat Islam. ${ }^{14}$

Aktivitas ijtihad merupakan sebuah keniscayaan untuk terus dilakukan oleh setiap mujtahid di setiap zaman guna menjawab dan memberikan solusi atas problematika kehidupan sosia yang sesuai memiliki relevansi akurat dengan tiap masa dan zamannya. Sejarah telah membuktikan keniscayaan ijtihad ini, sejak dari masa Rasulullah hidup dan meneirima wahyu hingga abad modern, dinamika ijtihad terus dan terus akan dibutuhkan serta berkembang. ${ }^{15}$

Dari penjelasan di atas menunjukan bahwa kedua sumber hukum, Alquran dan Sunnah terdapat teks-teks yang sebagian bersifat qath'i (aksiomatik) dan sebagian lagi bersifat zhanni (hipotetik). Dalam teks-teks yang zhanni inilah intervensi akal manusia dimungkinkan melakukan interpretasiinterpretasi dan penyesuaian pemaknaan dengan tuntutan perubahan social melalui aktivitas yang disebut ijitihad. Bahkan tidak hanya teks-teks zhanni saja,

\footnotetext{
${ }^{12}$ Ibid, h. 49

${ }^{13}$ Djazuli, Ilmu Fiqh Penggalian, Perkembangan dan Penerapan Hukum Islam (Jakarta: Kencana Prenada Media Grouf, 2005), 72.

${ }^{14}$ Gibtiah dan Yusida Fitriati, "Perubahan Sosial Dan Pembaruan Hukum Islam Persperktif Sadd Al-Dzari'ah," Jurnal Nurani Vol 15, no. No. 2 (Desember 2015): h. 101.

15 "View of Aplikasi Fiqh Al-Waqi': Pertimbangan Aspek Sosiologis Dalam Pemikiran AlQaradhawi," diakses 3 Juni 2018, http://ejournal.metrouniv.ac.id/index.php/istinbath/article/view/798/788.
} 
teks-teks qath'i pun sebagaimana yang disebutkan di atas dapat mengalami perubahan. Disinilah letak fleksibelitas hukum Islam. Dan juga hubungan timbal balik antara hukum Islam dan perubahan social. Karena itu tidak berlebihan bila Hukum Islam diasumsikan sebagai hukum yang bersifat dinamis dan selalu relevan untuk setiap zaman, keadaan dan tempat. ${ }^{16}$

\section{PERUBAHAN SOSIAL}

Merupakan suatu hal yang sangat wajar dan normal bila seklompok masyarakat mengalami apa yang disebut dengan Perubahan dan perkembangan. Karena Perubahan itu merupakan bukti dan ciri, bahwa masyarakat itu eksis dan hidup. Perubahan masyarakat yang terjadi itu dapat berupa berubahnya tatanan social, tatanan budaya, tatanan ekonomi dan lain sebagainya. ${ }^{17}$ Ini berarti perubahan-perubahan yang terjadi tidak hanya bersifat parsial, pada aspek tertentu saja, akan tetapi bersifat menyeluruh, meliputi seluruh aspek kehidupan masyarakat baik yang materil wujud dan sifatnya, maupun yang immaterill. Karena itu definisi perubahan sosial menjadi sangat luas, tetapi secara umum dapat diasumsikan bahwa, pada prinsipnya perubahan sosial adalah sebuah proses yang memicu perubahan-perubahan dalam struktur, fungsi, dan system dalam masyarakat.

Sementara menurut Wilbert Moore sebagaimana yag telah dikutip oleh Robert H. Lauer, perubahan sosial adalah perubahan penting dari social structure, social structure yang dimaksud disini adalah pola-pola dari perilaku dan interaksi. Moore memasukannya dalam definisi perubahan social berbagai ekspresi mengenai struktur seperti norma, nilai, dan fenomena kultural. Definisi ini menunjukkan bahwa perubahan social adalah fenomena yang kompleks, menembus berbagai tingkat kehidupan social, dan mengindikasikan bahwa seluruh aspek sosial masyarakat itu mengalami perubahan yang berkelanjutan. Kalaupun ada Perbedaan, hanya berbeda pada tingkat perubahannya saja. ${ }^{18}$

\footnotetext{
${ }^{16}$ Musa, Tarikh al- Fiqh al-Islami (Mesir: Dar al-Kitab al-'Arabi, 1958), 14.

${ }^{17} \mathrm{http}$ ///berbagilmublog.blogspot.co.id/sejarah -sosial-hukum-Islam-Kontemporer. Html. diakses 2014.

${ }^{18}$ Robert H. Lauer, Perspektives on Social Change, Terj. Alimandan SU (Jakarta: Rineka Cipta, 2003), 14.
} 
Sedangkan Selo Soemardjan merumuskan, sebagaimana telah dikutip dalam Soejono Soekanto, bahwa perubahan sosial adalah perubahan yang ada dan terjadi pada lembaga-lembaga kemasyarakatan dalam masyarakat, dan memberi dampak pengaruh pada nilai-nilai sosial, sikap sosial, sistem sosial, dan pola-pola perilaku sosial antara kelompok masyarakat yang ada. ${ }^{19}$ Sejalan dengan itu dalam Abdulsyani, gilin dan gilin mengemukakan, bahwa perubahan sosial adalah variasi dari cara hidup yang acceptable dan aplicable. Perubahanperubahan itu bisa terjadi baik karena dipicu oleh perubahan kondisi geografis, komposisi penduduk, kebudayaan, idiologi, dan adanya difusi atau penemuan yang baru dalam masyarakat. ${ }^{20}$

Dari definisi di atas dapat di pahami bahwa perubaha social mengacu pada perubahan tatanan social dalam masyarakat atau perubahan cara hidup suatu masyarakat tentang sistem sosialnya, baik perubahan nilai-nilai, perubahan perilaku social, lembaga-lembaga social dan hubungan sosial yang disebabkan oleh perubahan kondisi geografis, kebudayaan, ideologi ataupun pengaruh yang dapat mempengaruhi kemajuan social dalam system kemasyarakatan. Perubahan ini dapat terjadi cepat atau lambat tanpa disadari oleh masyarakat, disukai maupun tidak disukai.

Di samping itupula penyebab terjadinya perubahan social disebabkan oleh perkembangan ilmu pengetahuan dan tekhnologi. Hal ini ditandai dengan adanya komunikasi modern dengan menggunakan tekhnologi yang berkembang pesat. Maka dengan penemuan-penemuan baru baik dalam bidang tekhnologi, sosial, maupun budaya, akan mendorong terjadinya revolusi, dan modernisasi masyarakat. Dengan demikian kejadian disuatu tempat dengan cepat dapat diketahui oleh masyarakat lain yang bertempat tinggal jauh dari pusat terjadinya peristiwa tersebut.

Oleh sebab itu masyarakat yang sosialnya masih dalam taraf tradisional secara bertahap berubah menjadi masyarakat modern. Suatu keompok Masyarakat dikatakan modern bila memiliki tanda modernitas tersebut, yaitu

\footnotetext{
${ }^{19}$ Soejono Soekamto, Sosiologi Suatu Pengantar, XII (Jakarta: Rajawali Press, 1995), 337.

${ }^{20}$ Abdulsyani, Sosiologi Skematika, Teori, dan Terapan (Jakarta: Bumi Aksara, 2007), 163.
} 
adanya apa yang disebut dengan pengetahuan dan tekhnologi. ${ }^{21}$ Masyarakat modern lebih mengedepankan rasionalitas dan lebih terbuka pada hal-hal yang baru. Dan pranata sosial, politik ekonomi dan budaya lebih berkembang. Dalam tata kerjanya lebih mengutamakan prinsip rasionalitas, analitik, kausal empiris dan obyektif.

Waktu yang berbeda, seperti perubahan dari masa klasik ke masa kontemporer, bisa menjadi salah aspek penilaian modern tidaknya sebuah komunitas masyarakat. ${ }^{22}$ Dimana kondisi sosial pada masyarakat klasik penuh dengan kesederhanaan, baik dalm struktur social, organisasi social, dan hubungan social. Kondisi sosial ini berbeda dengan masyarakat kontemporer yaitu kehidupan yang lebih modern, baik struktur, organisasi social, dan hubungan social yang modern. Era masyarakat kontemporer ditandai dengan terjadinya arus globalisasi, dimana meleburnya batas wilayah, termasuk menjadi kaburnya batasan budaya antarar dunia timur dan barat, fashion dan style tidak lagi menjadi monopoli masyarakat kelas tertentu, sehingga klasifikasi masyarakat atas, menengah, dan kelas bawah yang dulu tampak jelas berbeda sudah tidak lagi jelas perbedaannya, semua melebur dalam pencampuran. ${ }^{23}$

Masih ada banyak sekali faktor pemicu yang dapat mempengaruhi dan menjadi penyebab terjadinya perubahan sosial. Perbedaannya terletak pada sifat atau tingkat perubahannya. Perubahan yang terjadi, bisa saja menyangkut soalsoal yang sifatnya fundamental mendasar, dan bisa juga berupa perubahan yang sifatnya parsial dan berdampak kecil. Namun bagaimanapun sifat atau tingkat perubahan pada masyarakat dapat dianalisa dari berbagai segi tergantung kearah mana gerak (direction of change) perubahan dalam masyarakat tersebut, bergerak kepada suatu perubahan yang sudah ada dalam old form/bentuk lampau ataupun bergerak kearah perubahan yang sama sekali baru/ new form.

\footnotetext{
${ }^{21}$ Pasaribu LL dan B. Simanjutak, Sosiologi Pembangunan (Bandung: Tarsito, 1986), 137.

${ }^{22}$ Opcit, Departemen....., 522.

${ }^{23}$ Supriyadi, sejarah Sosial Hukum Islam Kontemporer http://berbagilmublogspot.co.id/html. Diakses 22014.
} 


\section{DINAMIKA HUKUM ISLAM DAN PERUBAHAN SOSIAL}

Social development dan social changing pada sekelompok masyarakat merupakan hal yang pasti terjadi. Karena kedinamisan kehidupan masyarakat yang terus bergerak dan berubah-ubah, tumbuh dan berkembang. Perubahanperubahan bersifat menyeluruh, meliputi seluruh aspek kehidupan masyarakat sebagaimana yang telah dijelaskan dalam uraian sebelumnya. Oleh sebab itu sebagaiman definisi perubahan social di atas menjadi sangat luas. Akan tetapi secara meyeluruh penafsiran perubahan tersebut pada prinsipnya adalah merupakan proses yang melahirkan perubahan-perubahan di dalam struktur dan fungsi suatu sistem kemasyarakatan, yang terus bergerak secara sistematis, terukur dan continue kearah yang lebih sempurna.

Terkait dengan perubahan sosial, maka hukum Islam yang berfungsi sebagai pagar pengaman sosial atau pranata sosial, memiliki dua fungsi; pertama, sebagai kontrol sosial, dan kedua, sebagi nilai baru dan proses perubahan sosial. Jika fungsi yang pertama di tempatkan sebagai "cetak biru" Tuhan (Allah SWT) selain sebagai kontrol sosial juga sekaligus sebagai social engineering terhadap keberadaan suatu entitas dari masyarakat. Sementara yag kedua, lebih merupakan produk sejarah yang dalam batas-batas tertentu diletakkan sebagai justifikasi terhadap tuntutan perubahan sosial, baik dalam budaya dan maupun politik. Karena itu perubahan sosial akan berjalan pincang jika tidak ada alat kontrol terhadap interaksi sosial. ${ }^{24}$

Dalam hukum Islam perubahan sosial, budaya dan letak geografis suatu objek hukum, merupakan variabel urgent yang ikut menentukan bisa tidaknya, dan perlu tidaknya suatu perubahan hukum. Sebagaimana rumusan kaidah fiqih taghayyur al-ahkam bi taghayyur al-azman (tidak dapat dipungkiri bahwa berubahnya hukum dengan sebab berubahnya zaman). ${ }^{25}$

Terdapat tiga bentuk dialektika hukum islam dengan perubahan sosial yang dikenal secara umum, tahmil atau apresiatif terhadap perubahan, tahrim

\footnotetext{
${ }^{24}$ http//www.uinsgd.ac.id/multimedia/dokumen/makalah; Kontribusi Yusuf Al-Qaradhawi Bagi Pengembangan Pemikiran Hukum Islam Studi atas Fatwa-fatwa Kontemporer yang Berkaitan atas Fatwa-fatwa Kontemporer yang berkaitan dengan Tantangan perubahan Sosial. Tahun 2013. ${ }^{25}$ Ibn Qayyim al-Jauziyah, I'lam al-Muawaqi'in 'an Rabbi al-'Alamin (Beirut: Dar al-Fikr, t.t.), 14.
} 
atau menolak perubahan, dan taghyir atau memodifikasi perubahan. Dalam dialektika taghyir, perubahan sosial dimodifikasi sedemikan rupa agar subtansi dari perubahan itu tidak melenceng dari ketentuan-ketentuan yang ada dalam syariat. Artinya ada penyesuaian yang harus diberlakukan bagi perubahan sosial tersebut. ${ }^{26}$

Lebih lanjut Ibn Qayyim al-Jauziah telah merumuskan empat faktor sosial penyebab terjadinya perubahan hukum yaitu; 1). Situasi zaman, 2). Situasi tempat, 3) Sebab keadaan dan keinginan, dan 4). Adat atau tradis. Keempat faktor tersebut dirumuskan Ibn Qayyim al-Jauziah dalam kaidah fiqihnya yakni; taghayyur al-fatwa bi taghayyur al-zaman wa al-makan wa al-ahwal wa al-'adah27 (berubahnya fatwa dengan sebab berubahnya masa, tempat, keadaan/niat dan adat).

Dari rumusan kaidah taghyiru al-hukm ini dapat diketahui bahwa fatwa adalah hasil ijtihad seorang atau sekelompok mujtahid terhadap suatu peristiwa hukum syara' yang diajukan kepadanya. ${ }^{28}$ Hal ini dikarenakan Fatwa bersifat dinamis, dan dapat merespon perkembangan baru yang dihadapi masyarakat. apabila muncul setiap persoalan yang sifatnya baru yang belum jelas kedudukan hukumnya maka disinilah fatwa berperan untuk menjawab persoalan tersebut.

Akan tetapi terhadap perkara yang status hukumnya sudah jelas dan tegas, yang dinyatakan secara eksplisit dan rinci dalam al-Qur'an dan al-Hadist, tidak akan menimbulkan pro kontra dikalangan ulama mujtahidin dan umat Islam. Namun sebaliknya, terhadap peristiwa hukum yang belum jelas ketentuannya dalam kedua sumber hukum utama tadi, menuntut para ulama mujtahidin untuk memberi solusi dan jawaban yang cepat dan tepat agar hukum Islam menjadi responsive dan dinamis. Para Ulama dituntut untuk melakukan ijtihad ataupun mengeluarkan fatwa untuk menjawab persoalan tersebut untuk mengantisipasi dinamika sosial dengan kompleksitas persoalan yang

\footnotetext{
${ }^{26}$ Imron Rosyadi, "Dialektika Hukum Islam Dan Perubahan Sosial Di Indonesia: Telaah FatwaFatwa Tarjih Muhammadiyah," Tajdida: Jurnal Pemikiran dan Gerakan Muhammadiyah 12, no. 2 (15 November 2014): h. 124-125.

27 Ibid.

${ }^{28}$ Wahbah al-Zuhayli, Ushul al-Fiqh al-Islami, II (Dimashqi: Dar al-Fikr, 1986), 94.
} 
ditimbulkannya. Gerakan-gerakan dan kedinamisan kehidupan sosial di dalam masyarakat.

Syari'at Islam ditetapkan dan turunkan oleh Allah dengan maksud dan tujuan untuk mencegah al-fasad/kerusakan dan mendatangkan maslahat, juga menjadi dan memberikan acuan kebenaran, keadilan dan kebijakan yang harus diambil dan digunakan oleh umat dalam menjalankan kehidupan. Hukum Islam yang sangat fleksibel, dengan segala keunggulannya, merupakan aturan Allah yang di dalamnya pasti terkandung kebaikan, kemudahan dan kemaslahatan. Dengan demikian formulasi hukum Islam tersebut bertujuan untuk menjawab kebutuhan zaman dengan berlandaskan kepada maqasid al-syari'ah dan juga maslahah Mursalah.

Dalam mengejawantahkan Hukum Islam dapat dilakukan dengan dua pendekatan; pertama, hukum Islam diakomodir dalam hukum positif sehingga tercipta hukum positif Islam untuk masyarakat muslim. Kedua pengejawantahan nilai-nilai hukum Islam yag akan berlaku bagi seluruh masyarakat walupun diluar muslim. Kedua pendekatan tersebut akan menentukan eksistensi hukum Islam dalam sebuah Negara yaitu menjadikannya sebagai hukum nasional menuju perubahan sosial. Sebagaimana dinyatakan oleh Weber, bahwa suatu Masyarakat (kelompok sosial) akan selalu dipengaruhi oleh etika keagamaannya yang bersifat sangat normatif. ${ }^{29}$

Dari uraian tersebut di atas dapatlah dipahami bahwa hukum Islam orientasinya adalah kemaslahatan bagi hidup umat manusia secara keseluruhan. Hukum Islam dapat menjadi petunjuk dan memberi solusi terhadap permasalahan dan/atau problem yang timbul sesuai dengan perubahan yang ada dan terjadi pada sosial masyarakat, baik itu dalam bentuk penetapan hukum, maupun dalam bentuk suatu peraturan untuk menata kehidupan manusia itu sendiri.

Bagi Negara Islam yang memberlakukan hukum Islam dalam berbangsa dan bernegara, Hukum Islam dengan jelas dapat mengatur tingkah laku,

\footnotetext{
${ }^{29}$ Anthony Giddens, Kapitalisme dan teori Sosial Modern, terj. Soeheba Kramadribata (Jakarta: UI Press, 1986), 207.
} 
kedudukan, struktur dan lembaga pada masyarakat, misalnya negara Saudi Arabia, dan negara Islam lainnya. Sebaliknya terhadap negara yang bukan Islam, maka hukum Islam tidak serta merta dapat merubah sosial masyarakat.

Hukum Islam dapat merubah sosial pada negara bukan Islam apabila hukum Islam diakomodir dan dijadikan hukum positif. Seperti Negara Indonesia, ada hukum Islam yang diakomodir menjadi undang-undang nasional seperti Undang-undang No.1 Tahun 1974 tentang perkawinan. Masyarakat di Indonesia sebelum lahirnya UU No.1 Tahun 1974, orang sangat mudah menjatuhkan cerai kepada istrinya tidak melalui ligitasi atau non ligitasi. Tetapi setelah lahirnya UU No.1 Tahun 1974, maka perceraian tidak dianggap jatuh kecuali melalui ligitasi atau melalui pengadilan, artinya perceraian dapat terjadi di depan sidang pengadilan. Bahkan istri dapat menggugat cerai kepada suaminya apabila suami misalnya tidak memenuhi atau melalaikan tanggung jawabnya sebagai suami, maka dalam UU Perkawinan telah mengatur istri dapat mengajukan permohonan perceraian untuk suaminya ke pengadilan. Dalam hukum Islam perbuatan Istri tersebut disebut khuluk yakni pemberian hak kepada istri untuk memintakan perceraian kepada suaminya. Untuk menguatkan peranan atau kedudukan UU Perkawinan lahirlah Kompilasi Hukum Islam (KHI) sebagai hukum yang mengatur kehidupan sosial masyarakat muslim termasuk peerkara perkawinan.

Contoh lain dari diakomodirnya hukum Islam kedalam undang-undang nasional adalah UU. No. 21 Tahun 2008 yang mengatur transaksi ekonomi Islam. Aturan tersebut dimaksudkan untuk menguatkan sistem dan struktur serta lembaga sosial dan bisnis Islam, yang sebelum lahirnya UU tersebut transaksi ekonomi Islam dalam lembaga keuangan belum mendapat tempat yang kuat. Dengan demikian gamabaran bagaimana Hukum dapat melakukan perubahan sosial dalam masyarakat.

Menurut Raharjo apabila hukum dihadapkan kepada perubahan sosial, maka hukum memiliki dua fungsi; Pertama, hukum berfungsi sebagai kontrol sosial (social control). Hukum dilihat sebagai sarana untuk mempertahankan stabilitas sosial. Kedua, hukum dapat berfungsi sebagai sarana untuk mengubah 
masyarakat (social engineering). ${ }^{30}$ Ini menunjukan hukum dengan segala perangkatnya, memainkan peranannya untuk membawa perubahan sosial masyarakat kedalam suatu tatanan baru.

Para akademisi hukum Islam (ulama) tidak hanya memposisikan hukum Islam sebagai social engineering dan social control, akan tetapi lebih dari itu hukum Islam merupakan hasil pengejawantahan seorang hamba menjalankan keberagamaannya secara utuh dan absolut terhadap kehendak Allah. ${ }^{31}$

Hukum Islam yang bersumber dari al-Qur'an dan Sunnah merupakan peraturan dan tatanan yang datang dari Allah yang bertujuan untuk mengatur berbagai aspek kehidupan manusia. Namun perubahan sosial dan permasalahan sosial akan selalu tumbuh dan berkembang dan menuntut kepastian hukum.

Problematika yang dihadapi masyarakat terjadi dari berbagai aspek seperti pada aspek keluarga misalnya; Bank Air Susu Ibu (ASI). Aspek ekonomi misalnya; jual beli dengan menggunakan beberapa akad (al-uqud al-murakkabah) yang dilakukan oleh masyarakat ekonomi. Dari aspek kesehatan, tentang transplantasi organ tubuh manusia, bayi tabung, dan lain-lain. Problematika yang dihadapi masyarakat seperti tersebut di atas membutuhkan ketegasan hukum atau kepastian hukumnya.

Dinamisasi sebagai karakteristik hukum Islam mengindikasikan kemampuan hukum dalam mengakomodir, merespon dan menjawab setiap permasalahan yang tidak terdapat hukumnya dalam al-Qur'an dan Sunnah sebagai konsekwensi logis dari perubahan sosial yang tidak mungkin dielakkan. ${ }^{32}$

Perubahan hukum Islam merupakan realitas yang tidak dapat dipunkiri, perkembangangan diseluruh aspek kehidupan masyarakat sebagaimana tersebut di atas, hal ini telah membawa pengaruh yang besar terhadap suatu perubahan sosial masyarakat.

\footnotetext{
${ }^{30}$ Satjipto Rahardjo, Hukum dan Perubahan Sosial; Suatu Tinjauan Teoretis Serta PengalamanPengalaman di Indonesia (Yogyakarta: Genta Publising, 2009), 112.

${ }^{31}$ Retno Lukito, Hukum Sakral dan Hukum Sekuler; Studi Tentang konflik dan Resolusi dalam Sistiem Hukum Indonesia (Jakarta: Pustaka Alvabet, 2008), 73-87.

32 Ibn Rusyd, Bidayah al-mujtahid wa Nihayah al-Muqtashid (Indonesia: Dar al-Ihya' al-Kutub al'Arabiyyah, t.t.), 2.
} 


\section{KESIMPULAN}

Dari apa yang telah diurainkan di atas maka dapatlah disimpulkan bahwa dinamika adalah sebagai inti masyarakat, dengan demikian dalam situasi yang dinamis perkembangan hukum akan tertinggal, jika perubahan sosial tidak diikuti oleh perubahan hukum atau penyesuaian hukum, pada saat tertentu, hukum tidak lagi memenuhi kebutuhan masyarakat.

Kondisi demikian mengakibatkan timbulnya ketidakseimbangan dalam perkembangan lembaga-lembaga sosial (social lag) yang mengakibatkan terjadinya kepincangan dan kesenjangan pada masyarakat. Atas dasar itulah, maka ijitihad dalam bidang hukum Islam dalam rangka mengantisipasi perubahan sosial merupakan suatu hal yang mesti dilakukan. Sebab dengan ijitihad terhadap masalah-masalah yang belum ada kepastian hukumnya dalam al-Qur'an dan Sunnah akan dimungkinkan untuk melakukan reinterpretasi secara terus menerus, pengkajian ulang. Penalaran maksimal dilakukan untuk menghasilkan pemikiran yang orisinal terhadap sumber-sumber keislaman, dengan demikian hukum Islam tetap relevan bagi perkembangan dan perubahan sosial.

\section{DAFTAR PUSTAKA}

Abdullah Nashih 'Ulwan. Syari'at Islam yang Abadi. Bandung: Usamah Press, 1992.

Abdulsyani. Sosiologi Skematika, Teori, dan Terapan. Jakarta: Bumi Aksara, 2007.

Abu Zahrah. Ushul al-Figh. Mesir: Dar Al-'Arabiy, t.t.

Amir Syarifuddin. Ushul Figh I. Jakarta: Kencana, 2010.

Anthony Giddens. Kapitalisme dan teori Sosial Modern, terj. Soeheba Kramadribata. Jakarta: UI Press, 1986.

Departemen Pendidikan Nasional. Kamus Bahasa Indonesia. Jakarta: Pusat Bahasa, 2008.

Djazuli. Ilmu Figh Penggalian, Perkembangan dan Penerapan Hukum Islam. Jakarta: Kencana Prenada Media Grouf, 2005.

Gibtiah, dan Yusida Fitriati. "Perubahan Sosial Dan Pembaruan Hukum Islam Persperktif Sadd Al-Dzari'ah." Jurnal Nurani Vol 15, no. No. 2 (Desember 2015): 101-14. 
Ibn Manzur. Lisan al-'Arab. t.tp.: Dar al-Ma'arif, t.t.

Ibn Qayyim al-Jauziyah. I'lam al-Muawaqi'in 'an Rabbi al-'Alamin. Beirut: Dar alFikr, t.t.

Ibn Rusyd. Bidayah al-mujtahid wa Nihayah al-Muqtashid. Indonesia: Dar al-Ihya' al-Kutub al-'Arabiyyah, t.t.

Martha Mundhy. The Family Inheritence; And Islam: A Re-examination of the Sociology of Faraid Law, dalam Aziz Azmeh (ed.), Islamic Law Social and Historical Contexts. II. London: Routledge, 1998.

Muhammad Ali Jum'ah. Al-Madkhal Ila Darasat al-Madzahib al fighiyyah. Kairo: Dar al-Salam, 2004.

Musa. Tarikh al- Figh al-Islami. Mesir: Dar al-Kitab al-'Arabi, 1958.

Pasaribu LL, dan B. Simanjutak. Sosiologi Pembangunan. Bandung: Tarsito, 1986.

Retno Lukito. Hukum Sakral dan Hukum Sekuler; Studi Tentang konflik dan Resolusi dalam Sistiem Hukum Indonesia. Jakarta: Pustaka Alvabet, 2008.

Robert H. Lauer. Perspektives on Social Change, Terj. Alimandan SU. Jakarta: Rineka Cipta, 2003.

Rosyadi, Imron. "Dialektika Hukum Islam Dan Perubahan Sosial Di Indonesia: Telaah Fatwa-Fatwa Tarjih Muhammadiyah." Tajdida: Jurnal Pemikiran dan Gerakan Muhammadiyah 12, no. 2 (15 November 2014): 121-32.

Satjipto Rahardjo. Hukum dan Perubahan Sosial; Suatu Tinjauan Teoretis Serta Pengalaman-Pengalaman di Indonesia. Yogyakarta: Genta Publising, 2009.

Soejono Soekamto. Sosiologi Suatu Pengantar. XX. Jakarta: Raja Grafindo, 1995.

- - - Sosiologi Suatu Pengantar. XII. Jakarta: Rajawali Press, 1995.

"View of APLIKASI FIQH AL-WAQI': Pertimbangan Aspek Sosiologis Dalam Pemikiran Al-Qaradhawi." Diakses 3 Juni 2018. http://ejournal.metrouniv.ac.id/index.php/istinbath/article/view/798/788.

Wahbah al-Zuhayli. Ushul al-Figh al-Islami. II. Dimashqi: Dar al-Fikr, 1986.

Yoyo Hambali. "Hukum Islam Dan Perubahan Sosial : Study Atas Konsep Maslahah Dan Aplikasinya Dalam Keluarga Islam Kontemporer." Jurnal Maslahah Vol. 6, no. No. 2 (November 2015): 39-74.

Zulham Wahyudani, dan Raihanah Hj Azahari. "Perubahan Sosial Dan Kaitannya Dengan Pembagian Harta Warisan Dalam Perspektif Hukum Islam." Jurnal Islam Futura UIN Ar-Raniry Vol 14, no. No 2 (2015): h. 166-189. 